\title{
RESEARCH ON THE IDENTIFICATION OF THE ATTITUDE AND COMMITMENT OF COMPANIES IN THE BRASOV MUNICIPALITY ON THE PROGRAM "FRESH PRODUCTS" FROM OLYMPUS
}

\begin{abstract}
Alice-Ioana Munteanu ${ }^{6}$
Abstract: The research refers to the attitude and behavior of the managers of the hotel units in the city of Brasov regarding the new program born by those from Olympus. Other studies carried out on this topic have helped us to realize how important this program is and how aggregate it is. The program from olympus aims to market the fresh products of cow, sheep and goat respectively derived from them directly to hotel units that want to serve their customers with some of the best products on the market. The hypotheses are specific to the qualitative research the formulation is made after the research goals and the conception with which we will work have been defined. The assumptions from which we started are that the program is not very well known, which can lead to the failure of this project. The research is of a qualitative type, based on a questionnaire, carried out on a total number of subjects, taking place in Brasov. Following the questionnaire support, we managed to reach the following conclusions, whereby more than half of our respondents consider that this program set up by Olympus is highly appreciated by the aggregate of consumers of different ages. Another advantage is the attention paid to the relationship with, the consumer company trying to offer through this program besides products of superior quality and a safety to consumers. In short, this article represents a good development and vision of a huge Olympus company that wants to expand taking into account the needs and wishes of the clients.
\end{abstract}

Key words: OLYMPUS Fresh Products, identifying attitudes and behaviors, qualitative research

\section{INTRODUCTION}

Olympus Dairy is a dairy company in Greece. It is present in 34 countries and has five production units, 3 in Greece and one in Bulgaria and Romania. In 2010 the group recorded total revenues of 216 million euros.

The company entered the Romanian market in 1999, having a milk processing unit in Baraolt, Covasna county. From here, the milk was exported to Greek establishments, turned into dairy products and brought back to Romania. In 2011, the company completed an investment of 55 million euros in a production unit in Hălchiu commune, 15 kilometers from Braşov. The unit covers an area of 25,000 square meters and has a total milk reception capacity of 40,000 liters per hour and three

\footnotetext{
${ }^{6}$ Faculty of Food and Tourism, Transilvania University of Brașov, 29 Eroilor Boulevard, 500036, Brașov, Romania. ioaana.munteanu@yahoo.ro
} 
production lines: yogurt (120 tons / day), telema (100 tons / day) and milk (PET) : 16,000 liters / hour, Tetrapak packaging: 10,500 liters / hour). With the opening of the unit in Brasov, the factory in Baraolt was closed.

Olympus Romania posted in 2010 business of 20 million euros and a profit of about 48,000 euros. In 2011, the company's business rose to almost 23 million euros.

\section{THE PROGRAM OF FRESH PRODUCTS FROM OLYMPUS}

In 2018, Olympus made 30 million EUR investments in two new, high-tech production lines.

This year, Olympus was chosen as one of the most powerful brands in the country in the dairy category, within the Superbrands Romania 2017 Awards. by criteria such as quality, distinction and reputation.

In 2019 is a key point of Olympus development and it is also the moment when the company celebrates ten years since the products are on the shelf in Romania. "We are talking about ten years in which we have worked, dedicated and continuously developed, so that our products meet the expectations of consumers and serve their food needs.The program "Fresh products from Olympus was born in 2018-2019 and aims to market milk products and milk derivatives directly to businesses in Brasov municipality who always want fresh products for customers. The program aims to reach as many companies as possible to sell the products (Kleerebezem and Smid, 2006).

$\checkmark$ "As an improvement I think it is necessary to think about the possibility of delivering products throughout the day"

$\checkmark$ "I think it is necessary to supplement the quantity of food"

$\checkmark$ "The price will vary depending on the quantity ordered".

Key elements of the "Fresh Olympus Products" program

1. the quality of fresh products

2. A wide range of products

3. Affordable products (no other additions added)

4. Guaranteed and timely delivery

5. Free delivery

6. If customers are not satisfied with the products, they can chang 


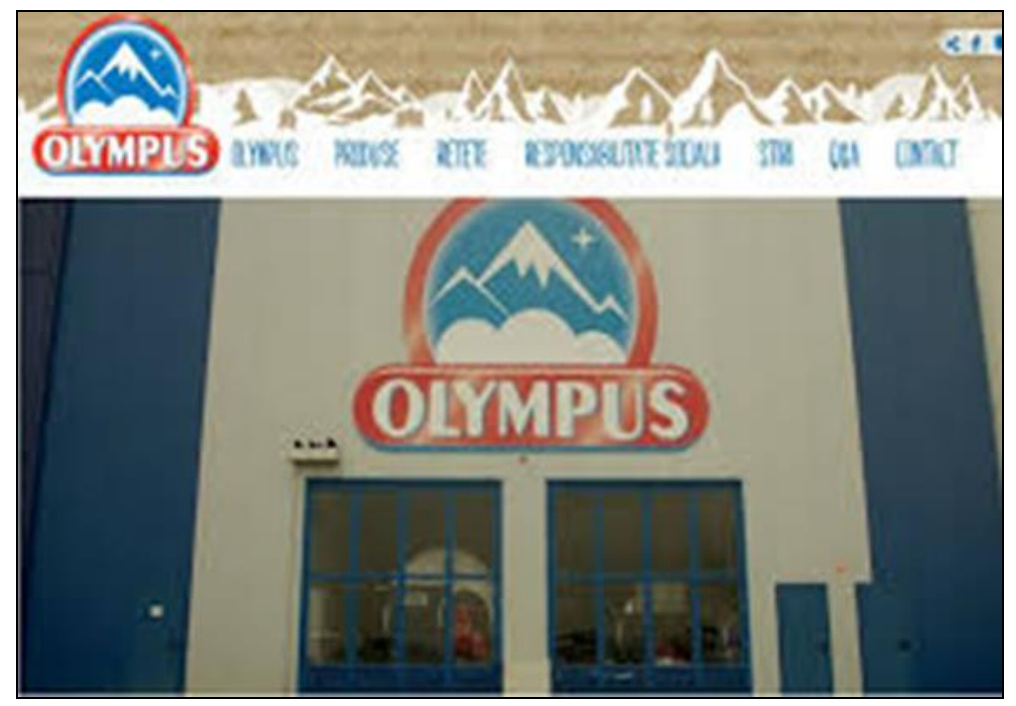

Fig.1. Olympus

The Greeks from Olympus continue their investments in the Hălchiu factory and focus on the Romanian market.

Athanasios Giannousis, commercial director of Olympus Romania, says that this year the company's business continued to grow after in 2018 the company exceeded the threshold of 100 million euros in turnover. Last year, the company's business increased by more than $10 \%$.

"The business is on an uphill slope, the market is very dynamic and the product range is diversified. In the first quarter we registered a double-digit increase (over 10\% - n.red.) For the Olympus dairy brand. There has been an increase in the market, the standard of living, they are positive signals. I am optimistic about the evolution of the market this year, "said the manager who has more than ten years experience in the consumer goods industry (FMCG) internationally, having previously held management positions both at Olympus Greece and in Romania, as production manager and sales manager (Macovei and Costin, 2006).

Athanasios Giannousis took over as commercial director in Romania in the first part of 2017. Olympus entered the Romanian market in 1999, initially having a factory in Covasna county. Subsequently, in 2011 he opened a production unit in Brasov county, after an initial investment of 55 million euros. However, subsequently Olympus continued the investments, reaching a total of 130 million euros invested locally from the market entry, according to the data provided by the company. The company has the brands Olympus, Oly, Fabrica Braşoveanu and Stragghisto in its portfolio. The last 
one was launched last year, the company investing in a new production line. Currently, Olympus's product portfolio includes more than 140 skis, including consumer milk and UHT, cream, yogurt, telemea, beverages, etc.

"We will continue to make investments, but not at such a high level. But we are trying to improve processes, both at the receiving side of milk, as well as at the processing and packaging side. We believe that whoever ceases to grow, ceases to be good. You have to adapt to the needs of the consumer".

The company with business of over 100 million euros last year focused initially on exports, but later the increase of the consumption from the local level balanced the balance of the company's sales. In 2012, the factory exported $80 \%$ of its production, according to the data presented by the company at that time. However, gradually the Romanian market became more and more important for the dairy producer. Thus, at present $45 \%$ of the total sales represents the export in 10-12 countries. Moreover, the Brasov Milk Factory, the company by which the Greek group owns the dairy factory locally, is the largest food exporter in Romania.

Among the top 500 exporters, Olympus ranks 192th, according to data from the National Institute of Statistics (Balaure, 2002)."The purpose of the factory is to serve the local market first and then to transform it into a regional center where we can supply all of Europe. Now 55\% of the production goes to the local market and the remaining $45 \%$ is exported." He also says that Olympus is gaining market share locally, but has also brought new consumers to certain segments such as Greek yogurt.As for the whole year, the manager says that there are positive signals in the market and that the manufacturer is trying to keep pace, although the competition is higher."Now consumers are paying attention to what they eat, they look at the label, they look at the place of production, if the raw material is brought to Romania and we try to meet the consumer's requirements."(Cătoiu and Teodorescu, 2002).

\section{RESEARCH METHODOLOGY}

"Marketing research concerns the process of investigation, collection, filtering, processing, analysis, interpretation, exploitation and dissemination of information, which describes a marketing situation, in order to substantiate a decision. Marketing research finds the shortest path to the customer and reduces the risk of decisions. The present research is a study conducted with the unit managers, based on a questionnaire, a case study drawn up with the purpose of identifying the attitude and behavior of the enterprises in Brasov municipality. 


\begin{tabular}{|c|c|c|}
\hline $\begin{array}{c}\text { Basic aspects } \\
\text { which the program } \\
\text { from Olympus is } \\
\text { known and } \\
\begin{array}{c}\text { aggregated directly } \\
\text { in the hotel } \\
\text { restaurants. }\end{array}\end{array}$ & $\begin{array}{c}\text { Researcher's questions } \\
\text { 1. To what extent are } \\
\text { of the system for selling } \\
\text { Olympus products in hotel } \\
\text { restaurants? }\end{array}$ & $\begin{array}{c}\text { Researcher's objectives } \\
\text { 1. Determining the extent to } \\
\text { which hotel consumers are } \\
\text { aware of the Olympus } \\
\text { program? }\end{array}$ \\
$\begin{array}{c}\text { 2. The structure } \\
\text { under which the } \\
\text { application for this } \\
\text { program will be } \\
\text { manifested. }\end{array}$ & $\begin{array}{c}\text { 2. What is the attitude of } \\
\text { potential consumers } \\
\text { towards the Olympus } \\
\text { program? }\end{array}$ & $\begin{array}{c}\text { 2.Identify the reasons why } \\
\text { potential consumers are } \\
\text { willing to implement the } \\
\text { Olympus program? }\end{array}$ \\
\hline $\begin{array}{c}\text { 3. Profile of target } \\
\text { hotels. }\end{array}$ & $\begin{array}{c}\text { 3. What would be the } \\
\text { advantages perceived by } \\
\text { the potential consumers in } \\
\text { connection with the } \\
\text { implementation of the } \\
\text { program? }\end{array}$ & $\begin{array}{c}\text { 3. Knowing the reasons why } \\
\text { potential consumers are not } \\
\text { willing to accept the } \\
\text { Olympus program ? }\end{array}$ \\
$\begin{array}{c}\text { 4. Reasons why } \\
\text { potential consumers } \\
\text { accept this program. }\end{array}$ & $\begin{array}{c}\text { 4. What is the demand } \\
\text { scheme according to the } \\
\text { size of the company? }\end{array}$ & $\begin{array}{c}\text { 4. Identify the categories of } \\
\text { consumers who want to } \\
\text { consume through the } \\
\text { program? }\end{array}$ \\
\hline
\end{tabular}

\section{CONCLUSIONS AND PROPOSALS}

Olympus places great emphasis on product quality, while at the same time being attentive to the consumer behavior of customers, to their preferences and to market trends, in order to be able to constantly offer products tailored to their needs and requirements. Another advantage is the attention paid to the relationship with the consumer, the company trying to offer, in addition to products, authentic, memorable experiences. "We rely heavily on the universe we create around the products in our portfolio, on the inspiration that consumers need in establishing and creating eating habits. We play with the products, with their versatility, and we invite the consumer to create alongside new authentic mixes and recipes in the kitchen", completes the commercial director of Olympus Romania. Also in the benefits category is the fact that Olympus products, which are manufactured in Braşov, in the Hălchiu factory, are made from milk collected $100 \%$ from the Romanian farms. Also very important aspects are the company's attention and concern for society, consumers, employees and the environment, as well as Olympus values - trust, credibility, professional excellence and continuous development."One of the basic values is the desire to be 
actively involved in community issues, fighting to make the world a better place and to inspire others to follow our example" says the company representative.

The program brings a new chapter to Olympus.

\section{LITERATURE}

1. Anghel, I. (2004). Business to Business Marketing. Editura ASE

2. Balaure, V. (coord) (2002). Marketing, ediţia a II-a, Bucureşti: Ed. Uranus.

3. Boboc, X. (2006). Managementul calitatii prodiselor agroalimentare, București: Editura Ase

4. Costin, Segal, R. (2001). Alimente pentru nutritie speciala, Galati: Ed. Academia, Galati

5. Cătoiu, I. (coord) (2009). Tratat de cercetări de marketing, Bucureşti: Ed. Uranus,

6. Cătoiu, I., Teodorescu, N. (2002). Comportamentul consumatorului. Ediția a 2-a, Teorie şi practică, Bucureşti: Ed. Economica

7. Chelcea S. (2001). Tehnici de cercetare sociologică, Școala Naţională de Studii Politice și Administrative.

8. Drăgan, I., Demetrescu, M. (1996). Practica prospectării pieței, Bucureşti: Editura Europa, Nova

9. Florescu C., Coordonator, Marketing, Coediție Marketer (1998). Grup Academic de Marketing și Management, București

10. Macovei, V.M., Costin, M. (2006). Laptele- aliment medicament, Galati: Ed.Academia

11. Kleerebezem, M., E.J.Smid (2006). New probiotics, Food Eng. and Ingredients

12. Socaciu, C. (2001). Chimia alimentelor, Ed. Academicpres, Cluj Napoca

13. Stoian, C., Scortescu, Gh., Chintescu, Gh. (1981). Tehnologia laptelui si a produselor lactate. Bucuresti: Ed Tehnica

14. Tomasik, P.J., Tomasik, P. (2006). Prebiotics and Probiotics. American Association of Cerial Chemists 80 